\title{
Possible change in Irish climate and its impact on barley and potato yields
}

\author{
N.M. Holden ${ }^{\text {a,* }}$, A.J. Brereton ${ }^{\mathrm{a}}$, R. Fealy ${ }^{\mathrm{b}}$, J. Sweeney ${ }^{\mathrm{b}, \mathrm{c}}$ \\ a Department of Agricultural and Food Engineering (Bioresources Modelling Group), University College Dublin, \\ Earlsfort Terrace, Dublin 2, Ireland \\ ${ }^{\mathrm{b}}$ Department of Geography, National University of Ireland Maynooth, Maynooth, County Kildare, Ireland \\ ${ }^{\mathrm{c}}$ National Institute of Regional and Spatial Analysis, National University of Ireland Maynooth, \\ Maynooth, County Kildare, Ireland
}

Received 20 August 2002; received in revised form 19 November 2002; accepted 20 December 2002

\begin{abstract}
Climate change scenarios can be used with crop simulation models to predict the impact of climate change on agricultural production. Focusing on two specific arable crops: (i) barley, a currently successful cereal crop, well adapted to the Irish climate and a staple of the tillage production sector; and (ii) potato, a traditional root crop in Ireland, sensitive to water stress and also a staple of the tillage production sector, the impact of climate change on yield was determined using simulation models (in the DSSAT package) and downscaled output from a general climate model. Daily weather data stochastically generated from mean monthly values for baseline (1961-1990), 2055 (2041-2060) and 2075 (2061-2090) climate periods were derived for over 500 locations in Ireland (derived from HADCM3Ga1). Important points with respect to the expected change in climate were that rainfall becomes more seasonally extreme, and a relatively uniform increase in temperature of about $1.6^{\circ} \mathrm{C}$ over the country can be expected by the 2075 climate period. This change in climate is predicted to cause little change in the geographical distribution of barley yield, but grain yield in all areas is expected to increase with possibly a greater increase to the west. Potato yield in 2055 and 2075 is expected to fall for non-irrigated tubers. The impact is likely to be a severe loss of yield over most of the country by 2055. The implications of these findings are that barley will remain a viable cereal crop, and might find a greater role in livestock supplement feed supply (due to predicted drought losses effecting grass yield), but the irrigation demand for potato will be very significant, possibly making the crop non-viable for farmers, particularly in the east of Ireland where there will be competition for water in summer.
\end{abstract}

(C) 2003 Elsevier Science B.V. All rights reserved.

Keywords: Climate change; Ireland; Barley; Potato

\section{Introduction}

The impact of climate change on agricultural production in Ireland is related to three specific factors: atmospheric carbon dioxide concentration, precipita-

\footnotetext{
* Corresponding author. Tel.: +353-1-7167460; fax: +353-1-4752119.

E-mail address: nick.holden@ucd.ie (N.M. Holden).
}

tion and temperature. Temperature will be related to the incident radiation, the influence of air masses and the cloud cover, while precipitation will be related to the stability and temperature of air masses. The influence of carbon dioxide concentration depends on specific plant biology; $\mathrm{C}_{3}$ species will tend to benefit from elevated $\mathrm{CO}_{2}$ more than $\mathrm{C}_{4}$ species. There have been mixed experimental responses to elevated $\mathrm{CO}_{2}$ in potato. Gourdrain and de Ruiter (1983) found a 
slight negative response, Wheeler and Tibbitts (1997) found no response in tuber growth (only in above ground biomass), while Finnan et al. (2002) found a significant increase in fresh tuber weight. Simulation modelling suggests that potato should have a positive tuber yield response to elevated $\mathrm{CO}_{2}$. Fangmeier et al. (2000) found that elevated $\mathrm{CO}_{2}$ caused an elevated grain yield in barley as did Sœb $\varnothing$ and Mortensen (1996). In agricultural systems, the balance of crop type and competing weeds, and relative ability to utilise increased carbon dioxide in the atmosphere will have a significant impact on specific production systems. It is likely that weeds will adapt to climate change more rapidly than crops due to their genetic advantage (Bunce and Ziska, 2000).

Increased temperatures and changing seasonality of precipitation may have significant impacts on the operations of farms, the crops that can be grown and the necessary infrastructure to ensure successful farm enterprises. In Ireland rainfall is currently sufficient to ensure that very little irrigation is required for crops. However, for potato, drought stress is important and farmers in the east of Ireland already have to flood irrigate potato fields to ensure adequate yields. Given that an increased seasonality of water supply is predicted (Sweeney and Fealy, 2001), this may become problematic without the introduction of the necessary infrastructure. Competing demands for water in the summer may make irrigation uneconomical for tillage farmers.

In this paper, the impact of climate change will be viewed in terms of how precipitation, temperature, and radiation are predicted to change for Ireland over the coming century, and how that change will impact upon crop yields. The approach taken is to use mathematical simulations of crop growth to predict yield, driven by downscaled climate data derived from the output of a general climate model. This paper will focus on two specific crops: (i) barley because it is a currently successful cereal crop, well adapted to the Irish climate and a staple of the tillage production sector; and (ii) potato because it is a traditional root crop in Ireland, it is sensitive to water stress and it is also a staple of the tillage production sector. Currently in Ireland, barley accounts for about $70 \%$ of the area under cereal production, and $50 \%$ of the area under arable crop production (derived from Anon., 2001), therefore, it is a vital crop for Irish farmers and its future sustainability is of great importance. Potatoes account for about $5 \%$ of the land area under crop production (Anon., 2001), but are important because of the demand for potatoes by the Irish consumer. Culturally the potato is integrated with Irish society in a way that other arable crops are not, and therefore any potential change in its potential as a profitable crop is of great interest. It is the aim of this work to evaluate the change in climate that may occur in Ireland over the next century, and to assess the potential impact of this climate change in terms of yields for two very important crops: barley and potato. The primary impact will be assessed in terms of changes in yields, but the secondary impacts on farm systems and production will also be considered.

\section{Methods}

\subsection{Regional climate scenarios for Ireland}

There are a number of options for deriving climate scenario data to drive agricultural models at suitable resolutions as undertaken in this research. Direct output from General Circulation Model (GCM) simulations are largely inadequate for regional scale impact analysis due to the coarse spatial resolution employed by most GCMs filtering out important sub-grid, regional scale differences in climate. In order to overcome these difficulties and to provide useful local/regional scale climate scenarios for impacts modelling, a number of techniques have been developed which utilise direct output from a GCM, but also take account of the observed regional variations in climate. One such method is "pattern scaling" (Santer et al., 1990), whereby the difference between current and future GCM simulations are added to an observed climate baseline or time series. The output is the existing regional spatial pattern of climate largely replicated for future time slices, while the mean is 'phase' shifted up or down depending on the variable of interest. Another method for increasing the spatial resolution from a GCM requires running a nested "regional climate model" (RCM) whose boundary conditions are forced by a parent GCM. Currently, the output resolution of RCMs are typically of the order of $25-50 \mathrm{~km}^{2}$. Although the level of detail from an RCM is far greater than the original GCM, this method is computationally very intensive. A third 
method, "statistical downscaling", requires fewer simplifying assumptions than pattern scaling and is less computationally intensive than an RCM. Statistical downscaling was the technique adopted for this study.

Statistical downscaling seeks to establish empirical relationships between observed mesoscale variables, such as, pressure, vorticity, geopotential heights, and an observed climate time series, such as temperature, precipitation or radiation. The use of upper air variables is advantageous for two reasons: upper air variables account for a large proportion of the variance in local climate (Cavazos and Hewitsone, 2002), and it is assumed that GCMs simulate upper air variables more accurately than surface variables (such as precipitation) which are dependent on processes that are not resolved by large GCM grid sizes (Wilby and Wigley, 2000). As a consequence, the relationships between upper air and surface variables provide transfer functions which can then be applied to output data from GCMs for future time periods (Karl et al., 1990). Using this method, future climate scenarios can be generated at a regional scale. Implicit in statistical downscaling is the assumption that the derived relationships will remain stable under climate change conditions.

Data were compiled from a number of sources for generating and testing climate scenarios. For the period 1961-1990 (designated by the IPCC as the baseline against which climate change is measured) surface observations of precipitation, temperature and radiation were compiled from Met Éireann (Irish Meteorological Service) and British Atmospheric Data Centre (BADC) databases for the whole of Ireland (570 precipitation, 70 maximum/minimum temperature, and 35 incident radiation/sunshine hours observation locations). Upper air data for the 1961-1990 period were obtained from the National Centre for Environmental Prediction/National Centre for Atmospheric Research (NCAR/NCEP) reanalysis project for the spatial domain around Ireland. The choice of upper air variables was dependent on similar variables being produced by the GCM (Table 1). The reanalysis data was regrided from the NCEP grid $\left(2.5^{\circ}\right.$ latitude by $2.5^{\circ}$ longitude) to the GCM output grid resolution (2.5 latitude by $3.75^{\circ}$ longitude).

The GCM utilised was the Hadley Climate Model HadCM3, which is a coupled ocean-atmosphere GCM developed by the UK Meteorological Office as a version of their unified forecast and climate model. The
Table 1

Variables used to derive the transfer functions

\begin{tabular}{ll}
\hline Predictor variables & Level $(\mathrm{mb})$ \\
\hline Mean sea level pressure & Surface \\
$2 \mathrm{~m}$ temperatures & Surface \\
Specific humidity & Surface \\
Geopotential heights & $500,700,850$ \\
Relative humidity & $500,700,850$ \\
Geopotential thickness & $500-700$ \\
Geopotential thickness & $700-850$ \\
Geopotential thickness & $500-850$ \\
Predictands & \\
Precipitation & \\
Maximum temperature & Surface \\
Minimum temperature & Surface \\
Radiation & Surface \\
\hline
\end{tabular}

model has a grid size of about $240 \mathrm{~km} \times 278 \mathrm{~km}$ in the vicinity of Ireland with 19 vertical levels in the atmosphere and a time-step of $0.5 \mathrm{~h}$. The 20-level oceanic model employed in tandem with the atmospheric model operates at a resolution of $1.25 \times 1.25^{\circ}$ meaning each atmospheric grid cell has six oceanic grid cells associated with it, therefore the oceanic component of the model can simulate currents in a fairly realistic manner which is important for scenario modelling in the maritime climate found in Ireland.

Daily output for nine grid cells in the vicinity of Ireland was extracted from a HadCM3 run. Once isolated, only the grid specific to Ireland was utilised further. The particular run concerned (HadCM3Ga1) was based on historical increases in individual greenhouse gases from 1860 to 1990 and then partly on the emission scenario IS95a. This involved a $1 \%$ per annum rise in radiative forcing but no consideration of tropospheric ozone. The end product was a 'middle of the road' scenario which produces global temperature increases of approximately $+3.0^{\circ} \mathrm{C}$ by 2100 (IPCC, 2001) which was considered to be suitable for prediction of climate change impact on Irish agriculture. The resulting datasets were then used to generate climate scenarios for three different periods: 1961-1990 (baseline), 2041-2070 (2055) and 2061-2090 (2075). The difference between the modelled-future and modelled-current scenarios was calculated and added to the baseline observations to estimate a future climate scenario. It is important to note that using only 
Table 2

Validation summary using independent dataset for the period 1991-1997

\begin{tabular}{llll}
\hline Downscaled variables & Range of monthly values of Pearson's ' $r$ & Mean average error & Root mean square error \\
\hline Maximum temperature & $0.2-0.9$ & $0.04^{\circ} \mathrm{C}$ & $0.9^{\circ} \mathrm{C}$ \\
Minimum temperature & $0.5-0.9$ & $0.03^{\circ} \mathrm{C}$ & $0.8^{\circ} \mathrm{C}$ \\
Precipitation & $0.4-0.9$ & $0.3-30.0 \mathrm{~mm}$ & $24.0-48.7 \mathrm{~mm}$ \\
Radiation & $-0.1-0.6$ & $0.4 \mathrm{MJ}$ per day & $1.1 \mathrm{MJ}$ per day \\
\hline
\end{tabular}

one scenario and one GCM (HadCM3Ga1) means that the effect of deviations from the IS95a emissions scenario or factors specific to the HadCM3 model cannot be accounted for by measures of uncertainty. This is being addressed by current research in Ireland.

Statistical downscaling was carried out using approximately 250 precipitation, 65 maximum/minimum temperature, and approximately 35 radiation/sunshine hours observation locations. Due to the limited number of locations measuring radiation in Ireland, data from sunshine hours observations were converted to radiation (McEntee, 1980) in order to augment the radiation network (Sweeney and Fealy, 2001).

Testing of the downscaling was performed using an independent dataset of monthly data for the period 1991-1997 (Table 2). In general, temperature results were good, particularly for summer maxima. Minimum temperatures were predicted well for all seasons. Downscaling precipitation was less accurate at all times of the year due to the influence of local factors that could not be included in the downscaling methodology. Radiation gave acceptable results overall. Having tested the statistical models, the climate scenario data were used to derive a $10 \mathrm{~km} \times 10 \mathrm{~km}$ grid over the whole of Ireland using a regression model similar to that of Goodale et al. (1998).

The $\mathrm{CO}_{2}$ concentration for each scenario was estimated based on the assumption that levels would double from the 1990 level ( $365 \mathrm{ppm})$ by 2100 . On this basis, the level for 2055 was estimated to be $581 \mathrm{ppm}$, and $647 \mathrm{ppm}$ by 2075 . This is compatible with an estimated value of $550 \mathrm{ppm}$ by the middle of this century (Houghton et al., 1992). The simulation models used (see Section 2.3) use $\mathrm{CO}_{2}$ concentration as a given value for a particular climate situation based on these values.

In order to simulate crop growth for the baseline and future climate periods it was necessary to generate daily weather data for driving the specific simulation models. The crop simulation models used in this work were part of a suite of models assembled under US Government sponsorship since 1980 as the Decision Support System for Agricultural Technology Transfer (DSSAT, version 3.5) (http://icasanet.org/dssat; Tsuji et al., 1994). All of the models are well known from the scientific literature or are more recent adaptations based on established models to extend their use to alternative crops, and all have been thoroughly tested and incorporate the most recent information on each of the crops (Tsuji et al., 1994).

\subsection{Daily weather data generation}

The barley and potato models both required daily values of solar radiation, maximum temperature, minimum temperature and rainfall. To derive daily data from the monthly mean data available, a stochastic weather generator Simmeteo (supplied with the Weatherman module of DSSAT) was used (Geng et al., 1986). The main problem encountered with this method was the requirement to use monthly mean number of raindays to create the daily weather data. The number of raindays per month was not available for each $10 \mathrm{~km} \times 10 \mathrm{~km}$ grid square. Raindays data were available for some Met Éireann weather stations and an analysis of the relationship between the average total monthly rainfall and average number of raindays per month (Holden and Brereton, 2003) suggested that a general extrapolation could be achieved using the equations:

$N=0.26 \times P \quad($ where $P<100 \mathrm{~mm})$

$N=24.0+0.0189 \times P \quad($ where $P>100 \mathrm{~mm})$

to estimate number of raindays $(N)$ from total rainfall $(P)$ for each month for each of the $10 \mathrm{~km} \times 10 \mathrm{~km}$ grid squares. 
As a result of the stochastic weather generation approach, the monthly means of the output for 1 year may deviate significantly from the input and it is necessary to generate data for a sequence of years to obtain a set of data in which the monthly means reduce to the input means. A 30-year period was used and the crop models were run for each of the 30 years and the yield for each $10 \mathrm{~km} \times 10 \mathrm{~km}$ grid square represented the average of 30 simulations. Thirty years was a compromise between the need to economise on run-time and the need to accurately reflect crop production for the climate period. The suitability of this approach was evaluated by both a comparison between input data (the data supplied before stochastic simulation) and output means (the recalculated climate after generating 30 years worth of daily data), and a comparison between current crop yields and those predicated by the models.

\subsection{The DSSAT models}

\subsubsection{Barley}

The CERES-Barley model was developed from the CERES-Wheat model (Otter-Nacke et al., 1991) primarily by altering parameter values. Model variables are updated daily on the basis of weather data. The growth cycle of the crop is divided into developmental phases each with its own parameter values for growth rate and dry matter partitioning modified by cultivar, weather or other environmental factors. Developmental stage is linked to the emergence of main-stem leaves whose rate of appearance depends on thermal time. Growth rate is calculated as the product of absorbed radiation, which is a function of leaf area, using a constant rate of dry matter yield per unit radiation absorbed. Leaf area is incremented daily on the basis of available assimilate and specific leaf area. At each stage, deficits of soil water or nitrogen can affect the growth of the modelled crop. Cultivar specific data are taken account of in terms of genetic coefficients for cold tolerance, photo-period sensitivity, vernalisation requirement and rate of grain growth (Hunt, 1988). From the range of options available, the variety selected for use in the simulation was a generic type of Spring Barley for higher latitudes (99002-High Lat. Spring-IB001) which represents the most common type sown in Ireland.

\subsubsection{Potato}

The potato simulation model, SUBSTOR, is a generic model for root and tuber crops (Singh et al., 1998). The model shares many of the basic features of the CERES family of models. The principal differences are associated with the fact that flowering and seed production are of little importance in potato and these aspects are replaced by algorithms that describe tuber formation. As with the CERES models, the phenological development of the crop (tuber initiation) is controlled by cumulative temperature. Crop parameters are modified for different cultivars according to the cultivar to be simulated. The cultivar King Edward was chosen because it has been in use in Ireland for many years.

\subsection{The soil sub-model (DSSAT)}

It was considered necessary to include a soil component in the crop simulation modelling. While the crops are modelled in considerable detail, the soil sub-model is a relatively simple water-balance model. The parameters of the soil sub-model vary between soil types in regard to albedo, drainage rate, number, depth, textural composition and water characteristics of horizons. The water characteristics include water content at saturation, at field capacity and at the limit of extractable water. Root distribution between horizons is a soil characteristic, not a crop model output; the crop models simulate root growth but the distribution of roots between horizons is determined by the soil parameter.

Each model in DSSAT uses a common soil sub-model to estimate soil water changes during growth. The soil model requires a profile description and the soil properties that affect soil water balance. A digitised version of the General Soil Map of Ireland (Gardiner and Radford, 1980) was used to determine the dominant soil type of each $10 \mathrm{~km} \times 10 \mathrm{~km}$ grid square. The soils were then further simplified by grouping into seven classes: (i) Grey Brown Podzolic; (ii) Brown Earth; (iii) Acid Brown Earth; (iv) Podzol; (v) Gley; (vi) Peats; and (vii) Urban/water, because it was not possible to differentiate between more soil types in a meaningful manner. The map of the five soil types defined (not shown) was very similar to the 1969 soil map of Ireland (as presented by Cruickshank, 1972) from which the descriptive 
Table 3

FILEX control values for simulation control during model operation

\begin{tabular}{|c|c|c|}
\hline & Spring Barley & Potato \\
\hline Cultivar & High latitude Spring & King Edward \\
\hline Planting & $\begin{array}{l}\text { On } 16 \text { March } \\
225 \text { seeds } \mathrm{m}^{2}, 0.15 \mathrm{~m} \text { rows } \\
0.02 \mathrm{~m} \text { depth }\end{array}$ & $\begin{array}{l}\text { On } 16 \text { March } \\
5.1 \text { seeds } \mathrm{m}^{2}, 0.86 \mathrm{~m} \text { rows } \\
0.2 \mathrm{~m} \text { depth }\end{array}$ \\
\hline Fertiliser & 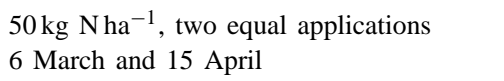 & $\begin{array}{l}200 \mathrm{~kg} \mathrm{Nha}^{-1} \text {, two equal applications } \\
6 \mathrm{March} \text { and } 15 \text { April }\end{array}$ \\
\hline Harvest date & At maturity (simulated) & 11 November \\
\hline \multicolumn{3}{|l|}{ For all model runs: } \\
\hline Number of replicates & 30 years (variable weather in site climate) & \\
\hline Soil & Site variable & \\
\hline Climate & Site variable & \\
\hline Initial soil conditions & Profile at field capacity & \\
\hline
\end{tabular}

terminology was derived. Grid squares dominated by Peats and Urban/water were excluded from the crop yield calculations, as were any grid squares with an average altitude over $150 \mathrm{~m}$.

\subsection{Model operation: starting conditions and crop management}

Using the DSSAT package, events are controlled by an experimental protocol entered in a control file called the FILEX. The generation of 30 years daily data for each climate period and each site was effected from the FILEX. For each of the 30 years of daily weather data, for each grid square the growth of crop was run for a single season and the results for 30 runs were averaged to produce a yield per grid square per climate period. There were $84510 \mathrm{~km} \times 10 \mathrm{~km}$ grid squares but with the elimination of sites over $150 \mathrm{~m}$ and those dominated by Peats and Urban/water, the number of grid squares processed was 560 . The FILEX also controls the treatments (date and method of planting, the date and rate of fertiliser application and of harvest - the data were obtained from Teagasc (the national agricultural advisory service) advisory guidelines (Teagasc, 2000) - and cultivar attributes to be used for the simulation (Table 3). Control of initial soil water status, number of replicates, the simulation start date, the detail of the method for weather generation and the form of output were also specified in the FILEX.
Prior to assessing the impact of climate change on the yield of barley and potato that may be expected in the future, the model output was compared with data from published Irish crop trials to ensure that the results for the baseline period were in line with yields obtained in the field (results are presented in Section 3.3).

\section{Results and discussion}

\subsection{Predicted climate change}

Baseline and future climate scenarios for 2055 can be seen in Fig. 1 (summer and winter temperatures) and Fig. 2 (summer and winter precipitation). At baseline, mean annual temperatures in Ireland exhibit a south-north gradient. This gradient tends to be more marked in the winter months of December to February than during the summer months of June to August. Baseline mean January temperatures are predicted to increase by $1.5^{\circ} \mathrm{C}$ by the middle of the century with a further increase of $0.5-1.0^{\circ} \mathrm{C}$ by 2075 . By 2055 , the extreme south and southwest coasts are predicted to have a mean January temperature of $7.5-8.0^{\circ} \mathrm{C}$ which will start extending further inland by 2075. By mid century, winters in Northern Ireland and in the north Midlands will be similar to those of Cork/Kerry (southwest) during the baseline period. Since temperature is a primary 


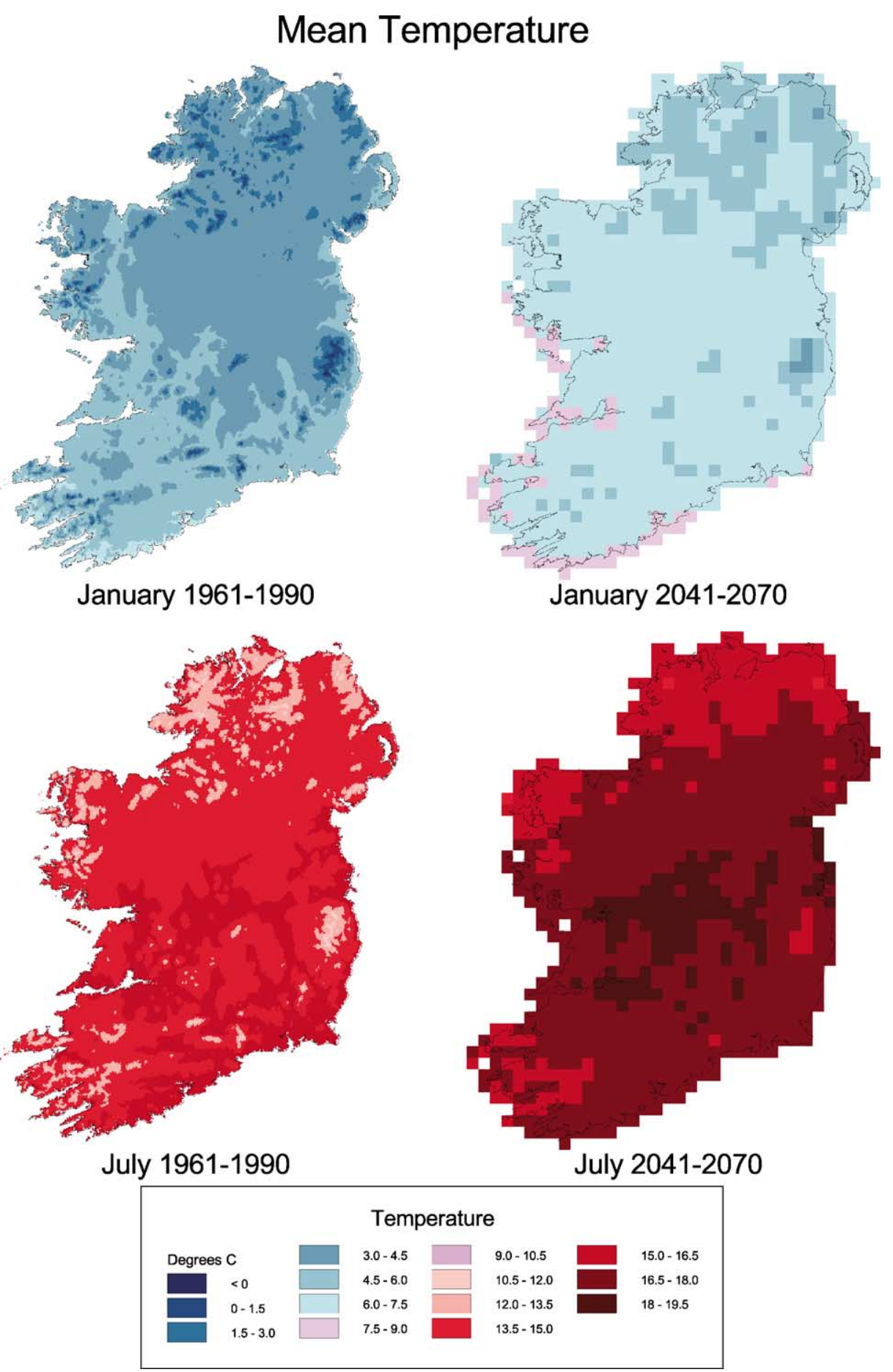

Fig. 1. Change in January and July temperature for baseline (1961-1990) and 2041-2070 climates. 


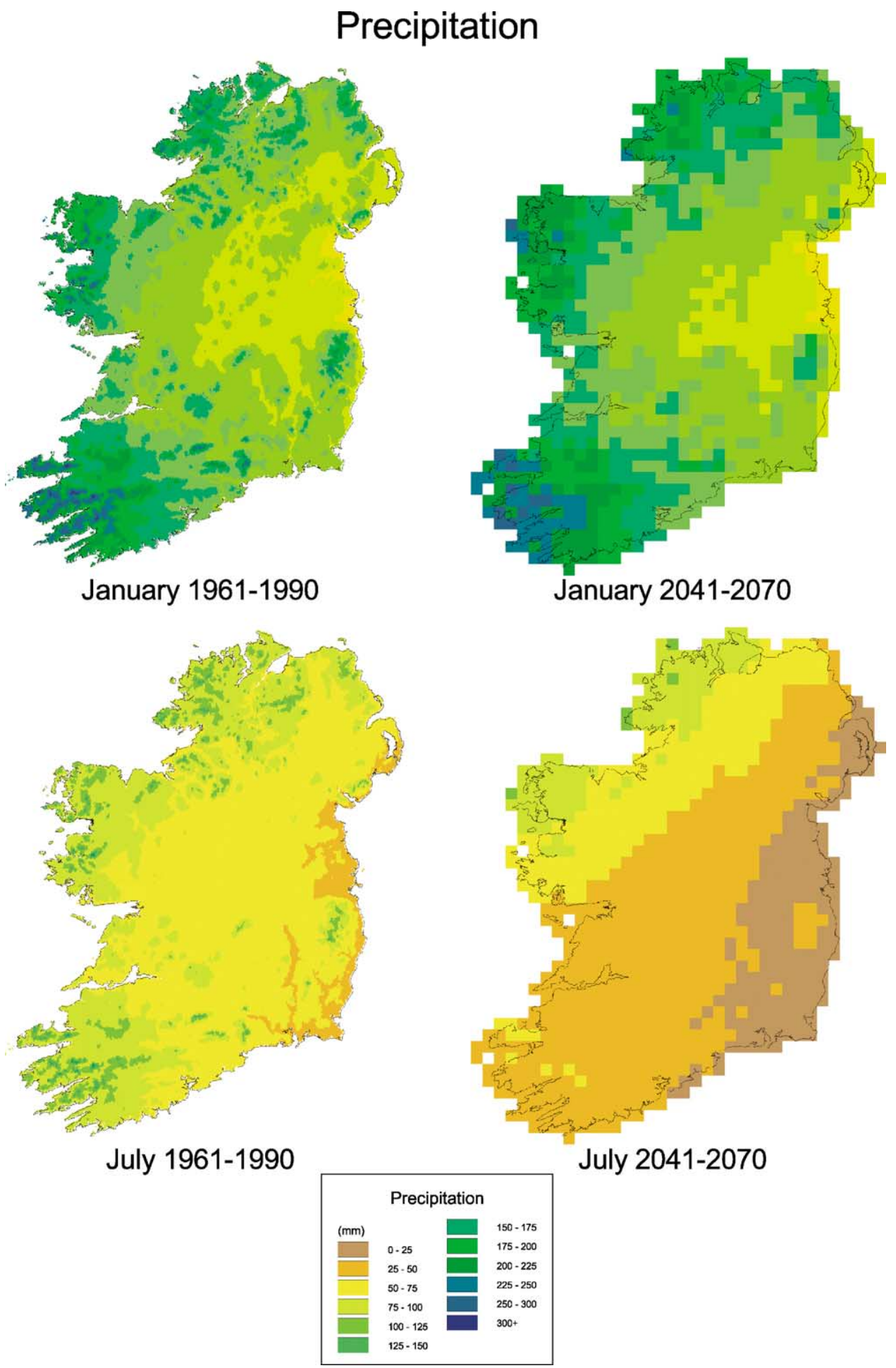

Fig. 2. Change in January and July rainfall for baseline (1961-1990) and 2041-2070 climates. 
meteorological characteristic, secondary factors such as frost frequency and growing season length can also be expected to undergo considerable changes. Signs of earlier springs and lengthening of the growing season over the past three decades have been detected both in the Irish instrumental record and in ecological events such as leaf unfolding and bird migration (Donnelly et al., 2001) which supports the suggested trend of the future scenarios.

Seasonally, spring temperatures are predicted to rise by $1.5^{\circ} \mathrm{C}$ between the baseline period and 2055 and further again by 2075. Summer temperatures demonstrate a similar pattern with slightly larger increases of $2.0-2.5^{\circ} \mathrm{C}$. Prediction of mean July temperatures indicates an overall increase of $2.5^{\circ} \mathrm{C}$ by 2055 and a further increase of $1.0^{\circ} \mathrm{C}$ by 2075 . Maximum July temperatures in the order of $24.5^{\circ} \mathrm{C}$ could be expected in the central Midlands. Autumn temperatures tend to show less dramatic increases and are approximately $1.0^{\circ} \mathrm{C}$ higher than baseline by 2055 with a further increase of $1.0^{\circ} \mathrm{C}$ by 2075 , by which time the extreme south and southwest coasts could be experiencing mean autumn temperatures of $12.5^{\circ} \mathrm{C}$.

Precipitation scenarios are inherently less reliable than temperature, given the inherent uncertainties of GCMs with respect to this spatially variable feature of climate (Burger, 1996; Wilby et al., 1998). However, an average monthly $R^{2}$ value of 0.51 was obtained for the training functions with baseline climate which suggests that some confidence could be placed in the future scenarios. The baseline geographical distribution of precipitation is largely dominated by orography with a marked west-east gradient (Fig. 2). This pattern is still visible in the 2055 and 2075 scenarios. Overall increases in precipitation, averaging $11 \%$, are predicted for the winter months of December to February. The greatest winter increases are suggested for the northwest (approximately $20 \%$ by mid century), but little winter change is predicted for the east coast and in the eastern part of the Central Plain. Decreases in rainfall of the order of $25 \%$ with decreases of over $40 \%$ in some parts of the southeast suggested for the summer months. Such decreases, if realised, would clearly have profound implications for agriculture and water resource management. Reductions on the southeast coast of similar magnitudes are also seen in the re- cently released UKCIPS02 scenarios generated from an RCM for the 2050 and 2080 periods with the Medium-High and High emissions scenarios (Hulme et al., 2002).

The baseline geographical distribution of radiation remains fairly similar to the current distribution in future scenarios, decreasing on a southeast to northwest axis. There are slight decreases predicted in autumn, winter and spring for 2055 and 2075. These may relate to changes in cloud cover during those seasons.

Important points with respect to the expected change in climate can be summarised as:

- a relatively uniform increase in temperature of about $1.6^{\circ} \mathrm{C}$ over the country will occur;

- little difference in temperature between 2055 and 2075 (only a slight increase);

- high rainfall sites get more seasonally extreme by a decrease in precipitation in spring and summer with little change in winter and a slightly wetter autumn;

- low rainfall sites become more seasonally extreme, with winters similar to the present but with markedly drier summers (the effect is seen by 2055 but does not get more extreme by 2075);

- average rainfall sites get more seasonally extreme by a decrease in precipitation in spring and summer with little change in autumn and winter (a slight increase in winter occurs);

- little difference in precipitation between 2055 and 2075 (only a slight increase).

\subsection{Daily weather data evaluation}

Comparisons between the original mean monthly climate data and those recalculated from the simulated daily weather data (three examples are shown in Table 4) show that the 30-year replicates provide an adequate weather dataset and that the use of an empirical relationship to estimate raindays from total monthly rainfall gives a very good rain dataset. A recurring feature of the generated data was an overestimate of July radiation. Little could be done about this problem. However, the relationship between photosynthesis and radiation takes the form of a rectangular hyperbola therefore by midsummer, photosynthetic activity would be occurring mainly at the upper end of the relationship where photosynthesis is close to 
Table 4

Comparison of input and mean output data from the daily weather generator for three test sites

\begin{tabular}{|c|c|c|c|c|c|c|c|c|c|}
\hline \multirow[t]{2}{*}{ Month } & \multicolumn{5}{|l|}{ Input data } & \multicolumn{4}{|c|}{ Output data } \\
\hline & Radiation & $T_{\max }$ & $T_{\min }$ & Rain & $R_{\text {days }}$ & Radiation & $T_{\max }$ & $T_{\min }$ & Rain \\
\hline \multicolumn{10}{|c|}{ Site at latitude 55 , altitude $231 \mathrm{~m}$ (northeast) } \\
\hline January & 2 & 5.4 & 0.1 & 152.5 & 28.0 & 1.7 & 6.1 & 0.0 & 146 \\
\hline February & 4.2 & 5.4 & -0.1 & 121.7 & 27.0 & 4.0 & 6.2 & -0.1 & 118 \\
\hline March & 7.6 & 7.3 & 0.8 & 116.8 & 27.0 & 8.5 & 7.3 & 0.3 & 120 \\
\hline April & 13.3 & 10.0 & 2.2 & 94.2 & 24.0 & 13.0 & 10.1 & 1.7 & 96 \\
\hline May & 16.4 & 12.7 & 4.4 & 86.9 & 23.2 & 16.4 & 13.8 & 4.3 & 81 \\
\hline June & 17.0 & 15.5 & 7.3 & 89.7 & 23.6 & 17.9 & 16.5 & 7.8 & 96 \\
\hline July & 15.0 & 16.8 & 9.2 & 91.6 & 23.9 & 16.9 & 17.5 & 9.4 & 91 \\
\hline August & 13.3 & 16.7 & 9.0 & 108.6 & 25.9 & 13.9 & 16.5 & 8.5 & 104 \\
\hline September & 9.2 & 14.5 & 7.4 & 129.1 & 27.4 & 9.5 & 15.2 & 7.7 & 124 \\
\hline October & 5.4 & 11.7 & 5.7 & 144.2 & 27.8 & 5.2 & 12.4 & 6.1 & 147 \\
\hline November & 2.7 & 7.8 & 2.1 & 148.3 & 27.8 & 1.8 & 8.9 & 2.0 & 139 \\
\hline December & 1.5 & 6.3 & 1.2 & 143.4 & 27.7 & 1.0 & 6.9 & 1.1 & 140 \\
\hline \multicolumn{10}{|c|}{ Site at latitude 54 , altitude $64 \mathrm{~m}$ (northeast) } \\
\hline January & 2.1 & 6.8 & 1.6 & 112.3 & 26.3 & 1.8 & 7.1 & 1.3 & 112 \\
\hline February & 4.4 & 6.8 & 1.4 & 87.0 & 23.2 & 4.4 & 7.2 & 1.0 & 82 \\
\hline March & 7.8 & 8.6 & 2.3 & 88.5 & 23.4 & 9.1 & 8.5 & 1.7 & 82 \\
\hline April & 13.3 & 11.0 & 3.6 & 68.3 & 19.9 & 13.7 & 12.3 & 3.8 & 65 \\
\hline May & 16.9 & 13.7 & 5.9 & 65.9 & 19.4 & 17.3 & 14.9 & 5.8 & 63 \\
\hline June & 17.5 & 16.5 & 8.7 & 71.3 & 20.5 & 18.0 & 16.7 & 8.4 & 76 \\
\hline July & 15.5 & 17.9 & 10.6 & 70.9 & 20.4 & 18.0 & 18.5 & 10.6 & 67 \\
\hline August & 13.4 & 17.8 & 10.4 & 87.1 & 23.2 & 13.8 & 17.5 & 10.2 & 89 \\
\hline September & 9.2 & 15.8 & 8.9 & 100.9 & 25.1 & 9.2 & 16.1 & 9.2 & 97 \\
\hline October & 5.4 & 13.0 & 6.9 & 110.8 & 26.1 & 5.1 & 13.8 & 7.4 & 121 \\
\hline November & 2.7 & 9.3 & 3.5 & 112.0 & 26.2 & 1.9 & 9.7 & 3.0 & 110 \\
\hline December & 1.5 & 7.7 & 2.5 & 102.8 & 25.3 & 1.4 & 8.5 & 2.7 & 91 \\
\hline \multicolumn{10}{|c|}{ Site at latitude 53 , altitude $76 \mathrm{~m}$ (midlands) } \\
\hline January & 2.4 & 7.1 & 1.3 & 90.4 & 23.7 & 2.1 & 6.8 & 0.6 & 89 \\
\hline February & 4.6 & 7.3 & 1.2 & 63.9 & 19.0 & 5.4 & 7.7 & 0.8 & 58 \\
\hline March & 8.2 & 9.5 & 2.2 & 69.9 & 20.2 & 9.3 & 9.9 & 2.4 & 68 \\
\hline April & 13.0 & 12.1 & 3.4 & 57.3 & 17.5 & 13.4 & 12.6 & 3.1 & 56 \\
\hline May & 16.3 & 14.6 & 5.7 & 71.5 & 20.5 & 16.1 & 15.7 & 5.7 & 71 \\
\hline June & 16.9 & 17.9 & 8.7 & 64.7 & 19.1 & 17.6 & 18.1 & 8.7 & 68 \\
\hline July & 15.4 & 19.4 & 10.6 & 59.7 & 18.0 & 17.6 & 19.8 & 10.8 & 58 \\
\hline August & 13.2 & 19.0 & 10.3 & 80.7 & 22.2 & 13.4 & 18.9 & 10.7 & 81 \\
\hline September & 9.8 & 16.6 & 8.5 & 82.0 & 22.4 & 9.9 & 17.2 & 9.0 & 72 \\
\hline October & 5.8 & 13.4 & 6.5 & 89.6 & 23.6 & 5.2 & 13.0 & 6.1 & 85 \\
\hline November & 3.1 & 9.5 & 2.9 & 87.0 & 23.2 & 2.7 & 10.3 & 2.4 & 81 \\
\hline December & 1.9 & 7.9 & 2.1 & 89.9 & 23.6 & 1.7 & 8.7 & 2.3 & 91 \\
\hline
\end{tabular}

$\overline{T_{\max }}=$ mean maximum monthly temperature $\left({ }^{\circ} \mathrm{C}\right) ; T_{\min }=$ mean minimum monthly temperature $\left({ }^{\circ} \mathrm{C}\right) ;$ rain $=$ mean monthly rainfall $(\mathrm{mm})$; $R_{\text {days }}=$ predicted monthly raindays; radiation $=$ mean monthly radiation $\left(\mathrm{MJ} \mathrm{m}^{-2}\right)$.

its maximum rate for a managed plant population. An important feature of the comparison is that although there are differences between input and output means they are small compared to the differences between sites and, especially, compared to the climate changes that are anticipated.

\subsection{Comparison of crop yields in Ireland and prediction by the models}

\subsubsection{Barley}

In European surveys, Irish barley production was estimated at $5.4 \mathrm{tha}^{-1}$ with a coefficient of variation 
of 11.4\% (Russell, 1990; Hough, 1990). The trends in barley yields during the period from 1955 to 1985 indicate that yields may be increasing by $0.7 \mathrm{tha}^{-1}$ per decade so that current yields should now exceed $6 \mathrm{tha}^{-1}$. In current practice, $6.1 \mathrm{tha}^{-1}$ is regarded as normal but may vary from a moderate yield of $4.9 \mathrm{tha}^{-1}$ to a "good" yield of $7.3 \mathrm{tha}^{-1}$ (O'Sullivan, 1999). In experimental trials by Teagasc in 1980-1981, barley (cv. Idri) yields ranged from 5.1 to $8.5 \mathrm{tha}^{-1}$ between different location (Conry, 1985). (Note that Spring Barley yields are normally reported at $18 \%$ water content in Ireland and the DSSAT output discussed is dry matter.) National mean yield predicted for the baseline climate was $6.3 \mathrm{tha}^{-1}$ (dry matter, which equates to $\sim 7.4 \mathrm{tha}^{-1}$ at $18 \%$ water content), ranging from 2.4 to $8.6 \mathrm{tha}^{-1}$. It was, therefore, concluded that the model was predicting Spring Barley yields that were realistic for the baseline climate period. For baseline climate, harvest date ranged from day 204 to 222 with a mean of day 212 (end of July).

\subsubsection{Potato}

In a European survey of crop production (Hough, 1990), main crop potato yield for the late 1980s in Ireland was given as between 30 and $35 \mathrm{tha}^{-1}$. In current farm practice, $29.4 \mathrm{tha}^{-1}$ is regarded as a normal yield (saleable yield) for main crop with yields ranging from moderate yields of $25.5 \mathrm{tha}^{-1}$ to good yields of $34.3 \mathrm{tha}^{-1}$ (O'Sullivan, 1999). In potato variety comparisons by The Department of Agriculture, Food and Rural Development carried out between 1996 and 1999, average yield of marketable potatoes (40-80 $\mathrm{mm}$ in size) varied between varieties from 43.6 to $55.8 \mathrm{tha}^{-1}$ (Anon., 2000). In the year 2000, total yield varied from 60.26 to 69.55 and $73.49 \mathrm{tha}^{-1}$ between Midleton Co., Cork; Oldtown Co., Dublin; and Raphoe Co., Donegal. Model output values reported are dry matter and thus a factor of 5 allows comparison with reported values to account for water content. National mean yield predicted for the baseline climate was $36 \mathrm{tha}^{-1}$ tuber yield, ranging from 27 to $48 \mathrm{tha}^{-1}$ when calculated for sites with adequate rainfall. This is necessary to account for that fact that irrigation is common in potato production but has not been assumed in the model simulation. Including all sites, the mean potato yield was $15.6 \mathrm{tha}^{-1}$. The yield estimation from the potato model was considered to be acceptable for the baseline climate period.

\subsection{Changes in crop yield with climate change}

\subsubsection{Barley}

According to the simulation modelling, there was no limit to the establishment of barley either under the baseline or future $(2055,2075)$ climates. The baseline grain yields of barley varied between 4 and $6 \mathrm{DM} \mathrm{tha}^{-1}$ in the areas of the midlands, east and south coast where cereals are currently located. Elsewhere, in the north, west and southwest the estimated potential yield was between 6 and $8 \mathrm{DM} \mathrm{tha}^{-1}$ (Fig. 3). These yields were similar to reported values. In 2055 and 2075, the geographical distribution of yield potential is not predicted to change but the grain yield in all areas is predicted to increase, with possibly greater increases to the west. Along the east and south coasts, where baseline yields are relatively low, an increase to baseline mean levels is predicted. In the north, west, and southwest potential yields may increase markedly by 2055 and more so by 2075 . The impact of climate change is to increase the barley biomass and to increase grain yield so the grain:biomass ratio remains similar.

The baseline date of harvest of barley varies by 3 weeks between the north coast (10 August) and the south coast ( 23 July) (assuming planting on 16 March). In 2055 harvest date is expected to be earlier with a further advance in 2075 when harvest date, generally, will by earlier by about 3 weeks (still assuming the same sowing date). The change in barley grain yield appears to be related to precipitation rather than temperature, but harvest date is earlier at warm sites. This means that as sites get (overall) wetter, yields increase and harvest can occur earlier in the year due to the general warming as part of climate change. An examination of the relationship between final yield and rainfall during crop growth revealed that under the baseline climate, yield is not quite at the maximum possible, but with climate change, the straight-line relationship starts to curve off to a maximum grain yield with no further response to rainfall.

The data suggest that the effects of water deficit by 2055 are going to be significant for grain production in barley. Water deficit effects are perceptible where precipitation was less than $400 \mathrm{~mm}$, and the majority of sites were affected to some extent. At the most affected sites, grain yield was reduced to about $4.5 \mathrm{tha}^{-1}$ (at $150 \mathrm{~mm}$ precipitation) which represents a reduction of 


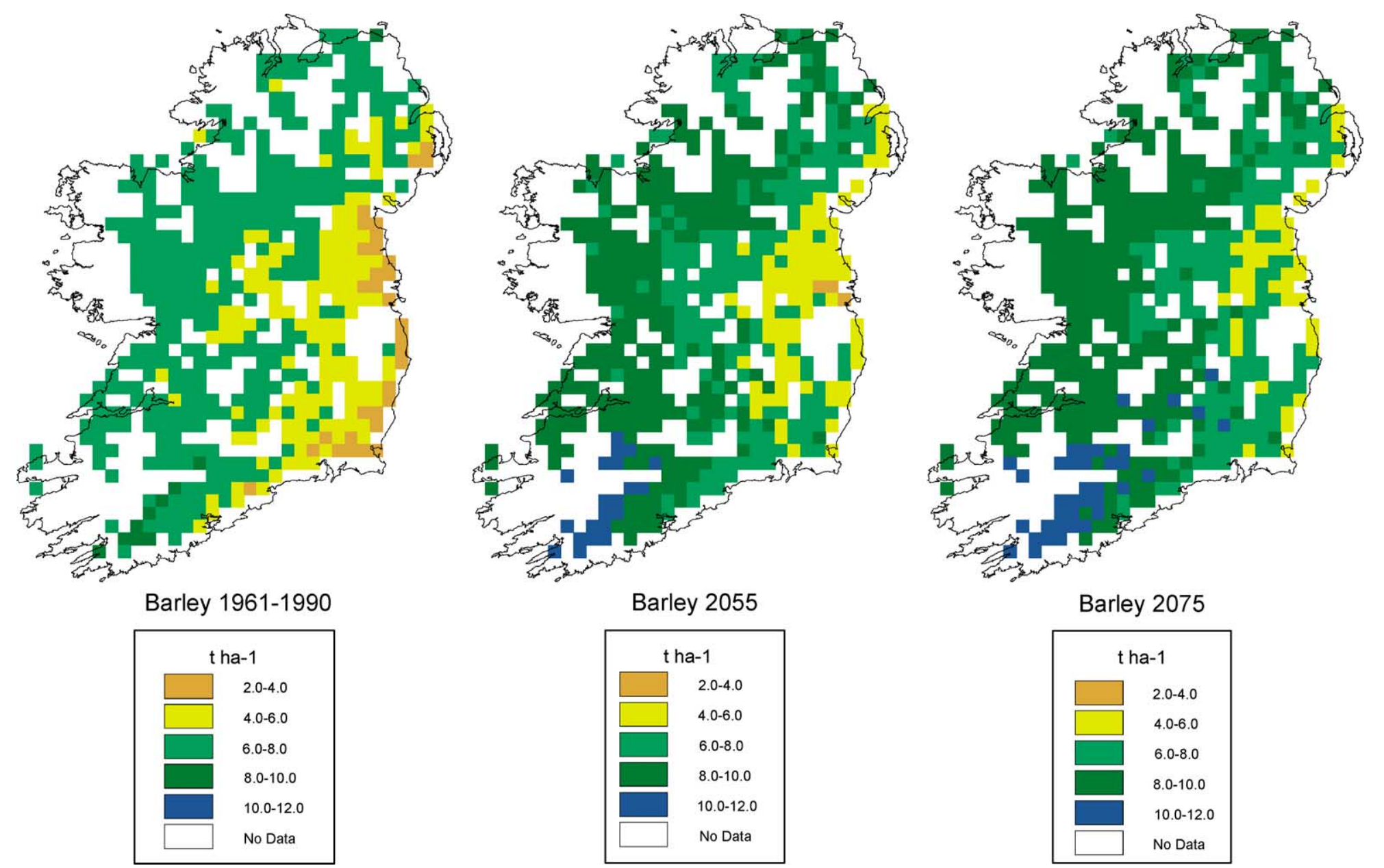

Fig. 3. Barley yield in Ireland under baseline (1961-1990) climate, and the change for the 2041-2070 and 2061-2090 scenarios. 
about $4.5 \mathrm{tha}^{-1}$ compared to the general level of yield at $400 \mathrm{~mm}$ precipitation during growth. The irrigation required to recover the loss would be about $250 \mathrm{~mm}$. The timing of harvest is important when considering the impact of the relatively sudden onset of winter rain with change in climate; when harvest is earlier relative to the onset of winter rain there will be less risk to the farmer of not being able to harvest crops.

In terms of the impact of climate change on crop productivity some fundamental impacts can be expected. The increase in temperatures will raise the potential for cereal production but the achievement of this potential will probably be limited by reduced summer rainfall. The increased predicted yield between 2055 and 2075 is probably attributable to the elevated $\mathrm{CO}_{2}$ because there is relatively little change in temperature and precipitation in that time period compared to the change between baseline and 2055 .

A potentially significant impact of the change in climate will be an alteration of the pest and disease prevalence and balance compared to the crop. The nature and type of spray requirement will evolve with climate, but it is quite likely that chemical intervention will increase with climate change. A northward migration of European weeds (that are not currently a problem in Ireland) may also be of significance, but this will very much depend on the exact nature of climate change and its balance with crop protection strategies. As barley can benefit from enhanced $\mathrm{CO}_{2}$, it may compete favourably with weed populations.

Livestock production is the main farming enterprise in Ireland at present. While livestock production is closely related to the seasonal pattern of grass production, the expectation of summer drought over a much greater area then at present may be expected to introduce the need for significant supplementation of grazed grass (Holden and Brereton, 2003). Barley is a potentially important source of energy for supplemental feeding of livestock. Any increases in cereal grain production may be expected to reduce the cost of feed barley. However, the extra costs associated with irrigation may offset any financial gain bringing its economic viability as a supplemental feed into question. Barley may also be in competition with maize as a forage crop by 2055 , thus the impact of climate change on maize production in Ireland also needs to be reviewed.

\subsubsection{Potato}

The geographical distribution of baseline tuber yield of non-irrigated maincrop potato reflects the high sensitivity of the crop to water deficiency (Fig. 4), but the estimated national average yield is still very close to that expected based on the findings of Hough (1990). In the humid western areas the estimated non-irrigated tuber yields vary between 25 and $50 \mathrm{tha}^{-1}$ (fresh weight @ 23\% DM). Biomass yields are currently highest in the west, and are likely to remain that way. In the lower rainfall areas of the east, non-irrigated yields are estimated at less than $15 \mathrm{tha}^{-1}$ (fresh weight). Tuber production closely follows total biomass, being about $86 \%$ of total biomass and this ratio stays fairly constant even with climate change. In 2055 and 2075, with the expected fall in summer and autumn rainfall yields of non-irrigated tubers are expected to decrease further. The impact can only be regarded as a significant, almost catastrophic, loss of yield over most of the country by 2055 with a slight yield recovery by 2075 . In the west, in 2075, baseline production levels are expected to be maintained. This impact is seen because the simulation was for non-irrigated potato.

The impact of rainfall during the growing season is that low rainfall sites have markedly lower yields than those with high rainfall (for the baseline climate). Potato tuber yield is particularly sensitive to water deficit and this appears to be reflected in the data. All sites were affected in 2055 but it is not possible to estimate the full scale of the effect. With irrigation, $12 \mathrm{tha}^{-1}$ (tuber dry weight) would be a normal yield for the baseline climate. The data for 2055 suggest that with $800 \mathrm{~mm}$ precipitation during growth, tuber yields of $6 \mathrm{tha}^{-1}$ were only $50 \%$ of potential yield. At the extreme, $300 \mathrm{~mm}$ of rainfall during growth resulted in negligible tuber yields. The data indicate that the irrigation requirement of the potato crop in 2055 would be substantial. By 2075 only the very wettest areas appear to be able to support a reliable non-irrigated potato crop which indicates that the impact of increased seasonality in precipitation will be very important in the future.

Miglietta et al. (2000) suggested that there has been too little research into root/tuber crop biology to be sure of the impact of climate change other than to suggest that increased water stress may reduce yields and that elevated $\mathrm{CO}_{2}$ may increase yields. These 


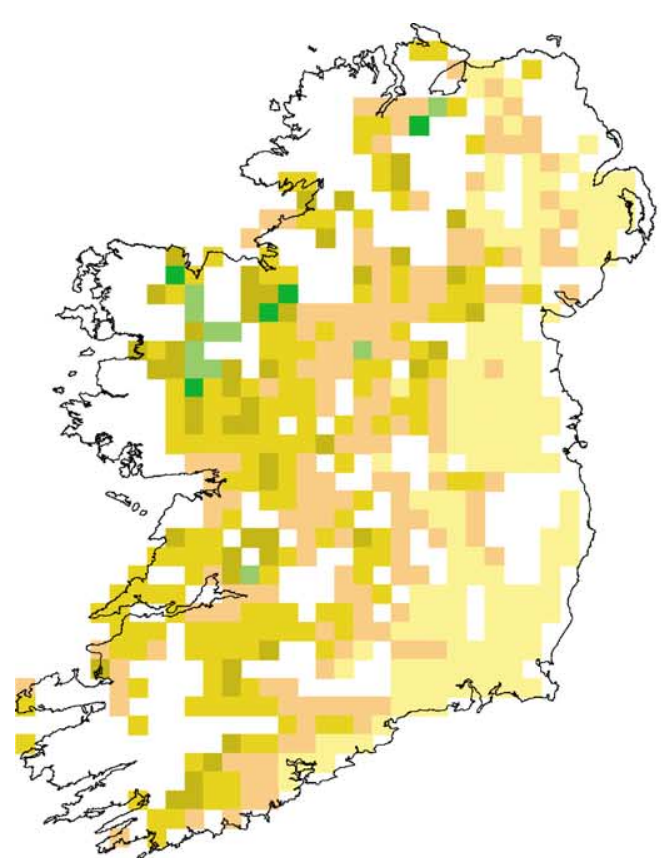

Potato $1961-1990$

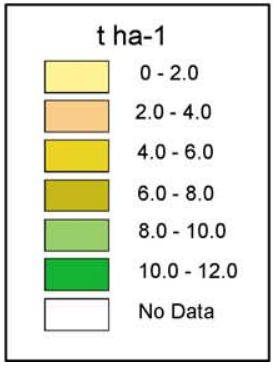

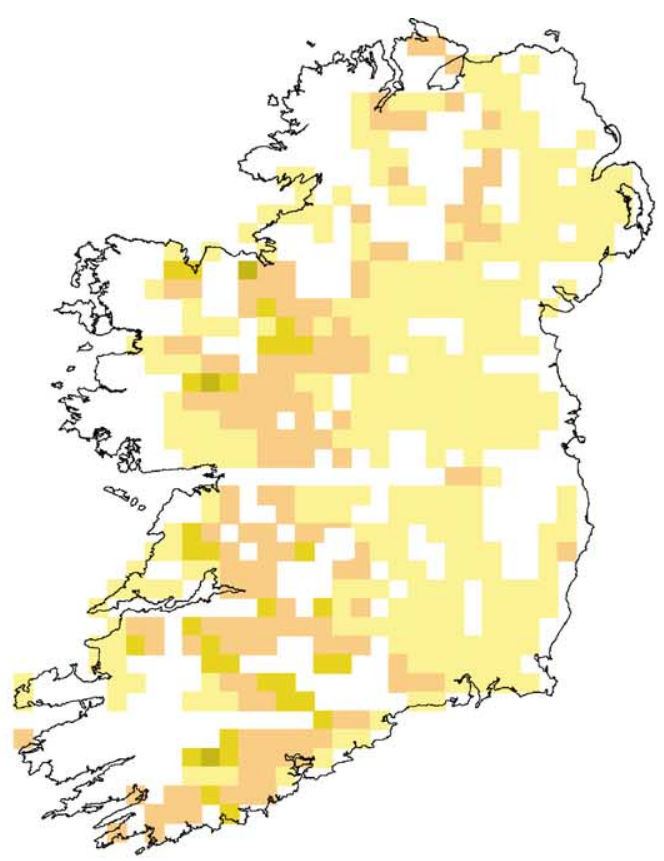

Potato 2055

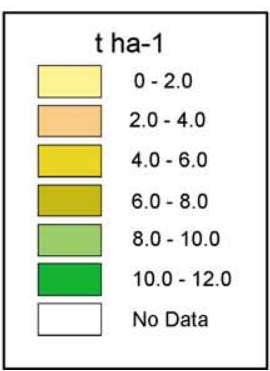

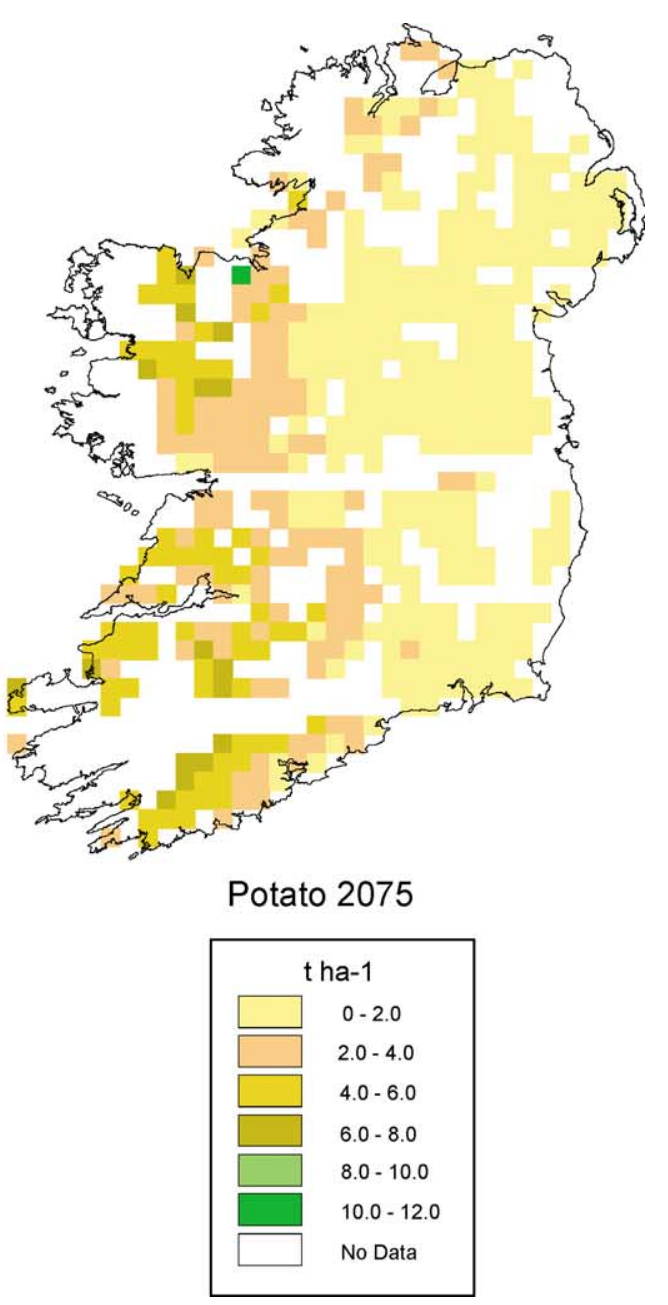

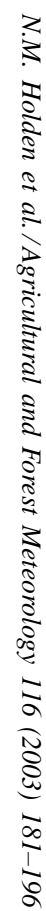

Fig. 4. Potato yield in Ireland under baseline climate, and the change for the 2041-2070 and 2061-2090 scenarios. 
general statements clearly apply to the predicted future climate of Ireland and its impact on potato yield. Peet and Wolfe (2000) suggested that increased atmospheric $\mathrm{CO}_{2}$ will enhance photosynthesis and improve water-use efficiency in vegetable crops provided there is no water or nutrient stress. This should be the case for potato which has a good transport capacity and large sinks (as argued by Finnan et al., 2002), but in the predicted future climate of Ireland, there is very likely to be water stress which will undermine the elevated $\mathrm{CO}_{2}$ advantage. The change in weed balance and its control discussed for barley also applies to potato.

As it is unlikely that the climate of Ireland will change sufficiently to cause temperature stress for potato crops the limiting factor in production will be the cost and availability of irrigation water. In the high water demand crop, potato, potential yields did not appear to be increased, but the effect of water deficit was very significant. The effects might be described as catastrophic but for the fact that the crop is normally irrigated in the present climate. With the projected scenarios, a much greater area of agricultural land will be affected by drought, and the quantities of water involved to compensate by irrigation will be large. Given that agriculture may have to compete for scarce summer water extraction with other users, the consequent economic effects may make crops with good potential uneconomical. The data have provided a reasonable estimate of expected irrigation need and clearly highlight the need for further investigation for medium- to long-term rural environmental planning.

\section{Conclusions}

The main conclusions that can be drawn from this work are that, as a result of climate change, there is likely to be no severe impact on barley, but the effect for potato will be very much dependent on the availability of irrigation water. It will be necessary to introduce systems for planning irrigation needs to ensure that water costs are acceptable and summer surface and ground water resources are not over used. For barley it can be concluded that:

(i) it remains a viable crop in yield terms with the predicted climate change; (ii) the impact of the change in winter and autumn precipitation on harvesting will not be a major problem due to the harvest becoming earlier in the year;

(iii) yield is closely linked to precipitation; and

(iv) it will remain an option as a forage crop.

For potato it can be concluded that:

(i) there will be water stress in the summer due to climate change;

(ii) a large irrigation requirement will develop if the crop is to continue to be grown;

(iii) viability as a commercial crop may be maintained only with irrigation;

(iv) irrigation systems will possibly require investment in infrastructure to store winter rain because of competing demands from ground and surface waters; and

(v) it is very likely that potato will cease to be a commercially productive crop in Ireland because of the reduced yield due to drought stress, difficulties with harvest due to the onset of winter rain in October, difficulties with tillage and planting due to very wet soils in spring and a possible increase in pest and disease problems.

\section{Acknowledgements}

This work was funded by the Environmental Protection Agency as part of the Research, Technological Development and Innovation Programme (RTDI) funded under the National Development Plan (2000-2006).

\section{References}

Anon., 2000. Potato Variety Evaluation 2000 Ireland. Department of Agriculture, Food and Rural Development, Dublin, Ireland.

Anon., 2001. Compendium of Irish Agricultural Statistics, 2001 (Euro Version). Department of Agriculture, Food and Rural Development, Dublin, Ireland.

Bunce, J.A., Ziska, L.H., 2000. Crop ecosystem responses to climatic change: crop/weed interactions. In: Reddy, K.R., Hodges, H.F. (Eds.), Climate Change and Global Crop Production. CAB International, Wallingford.

Burger, G., 1996. Expanded downscaling for generating local weather scenarios. Climate Res. 7, 111-128.

Cavazos, T., Hewitson, B., 2002. Relative performance of empirical predictors of daily precipitation. In: Proceedings of the International Modelling and Software Society 2002, 
Lugano, Switzerland, 24-27 June 2002, pp. 349-354 (http://www.iemss.org/iemss2002).

Conry, M.J., 1985. Comparison of the grain yield and quality of winter and Spring Barleys grown on four contrasting soils in Ireland. Ir. J. Agric. Res. 24, 201-212.

Cruickshank, J.G., 1972. Soil Geography. David and Charles, Newton Abbot.

Donnelly, A., Jones, M., McElwaine, L., Sweeney, J., Byrne, C., 2001. The use of biological indicators to detect climate change in Ireland. Poster presented at the 'Detecting Environmental change: Science and Society,' University College, London, 16-20th July 2001.

Fangmeier, A., Chrost, B., Hogy, P., Krupinska, K., 2000. $\mathrm{CO}_{2}$ enrichment enhances flag leaf senescence in barley due to greater grain nitrogen sink capacity. Environ. Exp. Bot. 44, 151-164.

Finnan, J.M., Burke, J.I., Jones, M.B., 2002. The effect of elevated concentrations of carbon dioxide and ozone on potato (Solanum tuberosum L.) yield. Agric., Ecosys. Environ. 88, 11-22.

Gardiner, M.J., Radford, T., 1980. General Soil Map of Ireland. An Foras Talúntais (now Teagasc), Dublin.

Geng, S., Penning de Vries, F.W.T., Supit, I., 1986. A simple method for generating daily rainfall data. Agric. For. Meteorol. 36, 363-376.

Goodale, C., Aber, J., Ollinger, S., 1998. Mapping monthly precipitation, temperature and solar radiation for Ireland with polynomial regression and a digital elevation model. Climate Res. 10, 35-48.

Gourdrain, J., de Ruiter, H.E., 1983. Plant growth in response to $\mathrm{CO}_{2}$ enrichment at two levels of nitrogen and phosphorus supply. 1. Dry matter, leaf area and development. Neth. J. Agric. Sci. 31, 157-169.

Holden, N.M., Brereton, A.J., 2003. An assessment of the potential impact of climate change on grass yield in Ireland over the next 100 years. Ir. J. Agric. Food Res. (in press).

Hough, M.N., 1990. Agrometeorological aspects of crops in the UK and Ireland. A Review for Sugar Beet, Oilseed Rape, Peas, Wheat, Barley, Oats, Potatoes, Apples and Pears. European Union, Luxembourg.

Houghton, J.T., Callander, B.A., Varney, S.K., 1992. International Panel on Climate Change, the Supplementary Report to the IPCC Scientific Assessment. Cambridge University Press, Cambridge.

Hulme, M., Jenkins, G.J., Lu, X., Turnpenny, J.R., Mitchell, T.D., Jones, R.G., Lowe, J., Murphy, J.M., Hassell, D., Boorman, P., McDonald, R., Hill, S., 2002. Climate Change Scenarios for the United Kingdom: The UKCIP02 Scientific Report. Tyndall Centre for Climate Change Research, School of Environmental Sciences, University of East Anglia, Norwich, UK.

Hunt, L.A., 1988. IBSNAT's genetic coefficients: coping with germplasm diversity. Agrotechnol. Transfer 7, 1-5.

IPCC (Intergovernmental Panel on Climate Change) 2001. Climate Change 2001: The Scientific Basis. IPCC Third Assessment Report. Geneva.

Karl, T.R., Wang, W.-C., Schlesinger, M.E., Knight, R.W., Portman, D., 1990. A method of relating general circulation model simulated climate to the observed local climate. Part I. Seasonal statistics. J. Climate 3, 1053-1079.

McEntee, M., 1980. A revision of the equation relating sunshine hours to radiation income for Ireland. Ir. J. Agric. Res. 19, $119-125$

Miglietta, F., Bindi, M., Vaccari, F.P., Schapendonk, A.H.C.M., Wolf, J., Butterfield, R.E., 2000. Crop ecosystem responses to climatic change: root and tuberous crops. In: Reddy, K.R., Hodges, H.F. (Eds.), Climate Change and Global Crop Production. CAB International, Wallingford.

O'Sullivan, M., 1999. The Irish Farmer's Handbook. Middlethird, Carrick-on-Suir, Ireland.

Otter-Nacke, S.J., Ritchie, J.T., Godwin, D., Singh, U., 1991. A User's Guide to CERES Barley-V2.10. International Fertilizer Development Centre, Muscle Shoals, AL, USA.

Peet, M.M., Wolfe, D.W., 2000. Crop ecosystem responses to climatic change: vegetable crops. In: Reddy, K.R., Hodges, H.F. (Eds.), Climate Change and Global Crop Production. CAB International, Wallingford.

Russell, G., 1990. Barley Knowledge Base. EU, Luxembourg.

Sœbø, A., Mortensen, L.M., 1996. Growth, morphology and yield of wheat, barley and oats grown at elevated atmospheric $\mathrm{CO}_{2}$ concentration in a cool maritime climate. Agric., Ecosys. Environ. 57, 9-15.

Santer, B., Wigley, T., Schlesinger, M., Mitchell, J., 1990. Developing climate scenarios from equilibrium GCM results. Hamburg. Report No. 47, Max Planck Institute für Meteorologie.

Singh, V., Matthews, R.B., Griffin, T.S., Ritchie, J.T., Hand, L.A., Goenage, R., 1998. Modelling growth and development of root and tuber crops, pages. In: Tsuji, G., Hoogenboom, G.T., Thornton, P.K. (Eds.), Understanding Options for Agricultural Production. Systems Approaches for Sustainable Agricultural Development. Kluwer Academic Publishers, Dordrecht, The Netherlands, pp. 129-156.

Sweeney, J., Fealy, R., 2001. Future climate scenarios for Ireland using high resolution statistical downscaling techniques. In: Paper Presented at Achievement and Challenge: Rio+10 and Ireland Conference, University College, Dublin, 10-14 September 2001.

Teagasc, 2000. Management Data for Farm Planning 2000. Teagasc, Dublin.

Tsuji, G.Y., Uehara, G., Balas, S. (Eds.), 1994. DSSAT version 3. International Benchmark Sites Network for Agrotechnology Transfer. University of Hawaii, Honolulu.

Wheeler, R.M., Tibbitts, T.W., 1997. Influence of changes in daylength and carbon dioxide on the growth of potato. Ann. Bot. 79, 529-533.

Wilby, R.L., Wigley, T.M.L., 2000. Precipitation predictors for downscaling: observed and general circulation model relationships. Int. J. Climatol. 20, 641-661.

Wilby, R.L., Hassan, H., Hanaki, K., 1998. Statistical downscaling of hydrometeorological variables using general circulation model output. J. Hydrol. 205, 1-19. 